\title{
Fermented Goat Milk Supplementation in Rats Hypercholesterolmic on Malonyldialdehyde and Description of Liver Histopathology
}

\author{
Chanif Mahdi ${ }^{1 *}$, Untari $\mathbf{H}^{2}$, Padaga ${ }^{2}$ \\ ${ }^{1}$ Faculty of Science Brawijaya University, Malang, Indonesia \\ ${ }^{2}$ Veterinary Medicinal Program, Brawijaya University, Malang, Indonesia
}

\begin{abstract}
Empirically, fermented milk product has been proven to improve and cure for several certain diseases. Bioactive peptides were produced through a fermentation process in goat milk promotes many benefits on body health. The present study revealed that goat milk was fermented using starter commercial 3\% to produced yoghurt increased protein content significantly. By using SDS- PAGE, showed that the decomposition of protein fraction was better than the fresh goat milk. Results then were analyzed by LC-MS/MS and found out that there were three kinds of bioactive each peptide consisted of 16 amino acids and were protected from the action of the protease enzyme. Goat's milk yoghurt was treated per oral in mice after hypercholesterolemic diet for 14 days with dose range of $300 \mathrm{mg} / \mathrm{kg} ; 600 \mathrm{mg} / \mathrm{kg}$; and $900 \mathrm{mg} / \mathrm{kg}$ for 4 weeks (28 days). The results demonstrated three type of bioactive peptides performed activity as antihypercholesterolemia on mice models which showed highly significant $(p<0.0 \mathrm{I})$ on the production of malondialdehyde (MDA) compared to control. Furthermore, goat milk yogurt also reduced MDA level and decreased fats accumulation in mice. Goat's milk yoghurt at dose of $600 \mathrm{mg} / \mathrm{kg}$ was able to provide the best therapeutic effect in lowering MDA level and with dose of $900 \mathrm{mg} / \mathrm{kg}$ also gave the best therapeutic effect in reducing the fat accumulation on liver. Based on histopathology observation, it was revealed that fermented goat milk reduced cells damage in liver. In summarize, these findings suggest that fermented goat milk promotes another activities as antihypercholesterolemia based on in vivo study.
\end{abstract}

Keywords: Fremented goat milk, hypercholeterolmia, malonyldialdehyde, liver hispathology

\section{INTRODUCTION}

Milk is the primary source of bioactive peptides which have various biological functions when compared with other food ingredients (Korhonen and Pihlanto, 2006). However, a bound state in the global protein, bioactive peptide in an inactive state, so that the necessary methods of hydrolysis or separation to separate bioactive peptide which is inactive to active. So that the utilization of milk as a food containing a bioactive peptide can be a maximum height (Ebrenger, et al., 2008 and Korhonen, 2009). It is therefore important to learn penjadi effective method to produce dairy products with sufficiently high content of bioactive peptides. Goat's milk is a natural functional food has a different chemical characterized with cow's milk, and has much in common with mother's milk. According Cullough (2003) lactose and protein content of goat milk is almost the same as cow's milk, but there are differences in protein struktrur and immunology. Besides goat milk contains medium chain fatty acids and globular. Fat in goat milk is relatively smaller compared with cow milk fat.

Fermentation with lactic acid bacteria (LAB) is a method that has long been used for dairy products. Empirically fermentation product has been shown to provide healthful effects and can cure some diseases (Donkar, et al., 2007). Some research says that the bioactive peptide produced by fermentation of milk has many benefits in the regulation of body systems that can provide substantial benefits to health (Sarmadi and Ismail, 2010). Some research indicates that bioactive peptides have activity as an antihypercholesterolemia through supplementation on rats model of hypercholesterolemia.

\footnotetext{
*Corresponding author e-mail: chanifmahdi@gmail.com
} 
Hypercholesterolemia is a condition cholesterol levels exceed normal limits. Normal cholesterol levels in humans 120 to $240 \mathrm{mg} / \mathrm{dL}$ In dogs 50 to 300/dL. White rats $40-130 \mathrm{mg} / \mathrm{dL}$ (Murrai, et al., 2003; Bauer, 2004).

Giving goat milk yogurt can provide a very real effect on rats hypercholesterolemia. Goat's milk yogurt contains antioxidant compounds that can capture free radicals produced as a side effect of bile acid synthesis. Antioxidant function as a catcher of free radicals and inhibiting lipid peroxidation process so that it can help reduce levels of free radicals as a result of the provision of hypercholesterolemia. Peroxidation inhibitor process dietary lipids by capturing free radicals and donate a hydrogen atom to form stable compounds that able to stop the chain reaction of lipid peroxidation.

Milk has biopeptida active content that can be generated through hydrolysis by the digestive enzymes and enzymatic processes by microorganisms. Lactic acid bacteria in yogurt can ferment milk to produce active biopeptida, such as lactoferrin.

Lactoferrin is able to repair cell damage by inhibiting the production of ROS in the cell membrane and works with vitamin $\mathrm{E}$ in limiting membrane lipid oxidation by ROS. Lactoferrin according to Guillen (2013) is an iron binding extracelullar. Intracellular iron called heme and stored in the form of ferritin, extracellular bound by transferrin or lactoferrin protein. Iron that is not bound will catalyze the production of ROS, then through biopeptide extracellular iron lactoferrin will be bound so that inhibited ROS generation.

Yogurt also contains lactic acid bacteria have enzymes Bile Salt Hydrolase (BSH) so as to deconyugate bile salts to produce bile salts that poorly absorbed by the small intestine. Bile salts return to the liver to be reduced so that the body uses cholesterol as a precursor to balance the amount of bile salts that decrease the amount of cholesterol. Decrease in cholesterol levels resulted in a decrease in the amount of lipids which are exposed to free radicals is reduced so that the process is reduced lipid peroxidation accompanied by a decrease in the sheer number of levels of MDA in the liver of animal models of rats (Rattus norvegicus) hypercholesterolemia.

\section{RESEARCH METHODS}

\section{Making Starter}

Making the starter is done according to the work instructions industries producing strater (www.yogourmet.com). Goat milk as much as 100 $\mathrm{ml}$ pasteurized at a temperature of $72^{\circ} \mathrm{C}$ for 5 minutes, then cooled to a temperature of $40^{\circ} \mathrm{C}-45^{\circ} \mathrm{C}$. Starter in the form of freeze-dried and weighed as much as 0.5 grams dissolved in $5 \mathrm{ml}$ of pasteurized milk (100 ml taken from pasteurized milk). Starter solution is added to $100 \mathrm{ml}$ goat milk, homogenized and incubated at $40^{\circ} \mathrm{C}-45^{\circ} \mathrm{C}$ for $4-8$ hours until the starter reaches a pH of 4.0 to 4.5 .

\section{Making Yogurt}

The procedures for making yogurt using methods Posecion, et al. (2005) were modified. 500 $\mathrm{ml}$ goat milk is pasteurized at a temperature of $72^{\circ} \mathrm{C}$ for 5 minutes and cooled to temperatures reaching $40^{\circ} \mathrm{C}-45^{\circ} \mathrm{C}$. Furthermore, inoculated with starter with a concentration of 3\% and 5\% (according to the study treatment), homogenized and carried incubation at $40^{\circ} \mathrm{C}-45^{\circ} \mathrm{C}$ for $4-8$ hours until the $\mathrm{pH}$ of the yogurt reaches 4.5-5. Yogurt produced freezedried (freeze dry) and then stored at $4-5^{\circ} \mathrm{C}$ until further analysis.

\section{Identification of peptides using LC/MS-MS}

Freeze dried peptide sample was dissolved in $5 \%$ acetonitril and $0.1 \%$ formic acid in deionized water for analysis of LC-MS/MS. Analysis LCMS/MS is done by using the LCQ Deca XP MAX Thermo system with electrospray ionization (ESI) (Thermo Scientific Inc, USA) with a C18 column BioBasic, diameter $150 \times 2.1 \mathrm{~mm}, 5 \mu \mathrm{m}$ particle size. LC-MS conditions that the gas flow rate of 50 arb, sprayer voltage of $4 \mathrm{kV}$, a capillary voltage of $20 \mathrm{~V}$ and a capillary temperature of $300^{\circ} \mathrm{C}$. MS scans performed over a range of $\mathrm{m} / \mathrm{z} 100-\mathrm{m} / \mathrm{z} 1600$ with a flow rate of $200 \mu \mathrm{L} / \mathrm{min}$. Peptide separation was performed using a linear gradient in the order of $5 \%$ solvent B to $70 \%$ solvent B $(0.1 \%$ formic acid in acetonitrile) for 90 minutes more. Mass spectral data is read using the program Thermo-Xcalibur TM (Thermo Sceintific USA). Data MS/MS-acquired Thermo Xcalibur ${ }^{\mathrm{TM}}$ processed into MGF file format using v2.3.2.0 Mascot Distiller (Matrix Science, 
London, UK). Blast is then performed by inserting MGF files to search engines v2.3 Mascot (Matrix Science, UK). Peptide sequences identified by conformity with peptide sequences contained in the database.

\section{Preparation Mice with Diet Hypercholesterolemia}

Diet feeding method hypercholesterolemia (Gani, et al., 2013), hypercholesterolemia diet feed consists of cholic acid $0.1 \%$, lard $10 \%$, and poached quail egg yolks fresh 5\%. All the ingredients are mixed and diluted with distilled water to a volume of $2 \mathrm{~mL}$. Feed hypercholesterolemia diet was administered daily for 14 days beginning on day 8 with force feeding method with sonde per rat for $3.02 \mathrm{gr} / 2 \mathrm{~mL}$. After that, the mice were given a drink and a standard feed SP 16.98 grams. Feed given as much as $20 \mathrm{~g} / \mathrm{head} / \mathrm{day}$. The composition of the feed material hypercholesterolemia in 20 grams of feed can be seen in Table 1 .

\section{Granting Therapeutic Goat Milk Yoghurt}

Goat's milk yoghurt therapy is given after the mice induced hypercholesterolemic diet for 14 days. Groups of mice were given the therapy that is in group $\mathrm{C}, \mathrm{D}$, and $\mathrm{E}$ at a dose of $300 \mathrm{mg} / \mathrm{kg}, 600$ $\mathrm{mg} / \mathrm{kg}$, and $900 \mathrm{mg} / \mathrm{kg}$. Therapy was given orally by stomach sonde of $1.5 \mathrm{~mL}$ for 4 weeks (28 days) beginning on day 22 .

\section{Measurement of MDA levels Making the Curve Raw MDA}

MDA standard kit stock solution with a concentration of $1,2,3,4,5,6,7$ and $8 \mathrm{mg} / \mathrm{mL}$ were taken of each $100 \mathrm{~mL}$. The solution was put into a different reaction tube and added $550 \mathrm{~mL}$ of distilled water and $100 \mathrm{~mL}$ of $100 \%$ TCA then homogenized degan vortex. Solution was added to $250 \mathrm{~mL}$ and
$100 \mathrm{~mL} 1 \mathrm{~N} \mathrm{HCl} \mathrm{Na-Thio} 1 \%$ into the tube and homogenized. Centrifugation at a speed of $500 \mathrm{rpm}$ for 10 minutes. Thereafter, heated for 30 minutes at $100^{\circ} \mathrm{C}$. The solution was allowed to stand at room temperature and the supernatant was taken and standard solutions is then read at maximum wavelength using a spectrophotometer. Absorbance MDA standard solution and made the curve.

\section{Measurement of MDA level}

As much as $1.0 \mathrm{~g}$ of rats hepar was cut into small peace, then crushed in the mortar, placed on cold block of ice. Then add $1 \mathrm{~mL}$ of $\mathrm{NaCl}$ fisiologis $0.9 \%$. Homoginat transferred into microtube and centrifuge at the speed of $8000 \mathrm{rpm}$ for 20 minutes. $100 \mu \mathrm{L}$ of supernatant was added $550 \mu \mathrm{L}$ distilled water. Then added $100 \mu \mathrm{L} \mathrm{Na-} \mathrm{thiobarbituric} \mathrm{acid.}$ All of each reagent homogenized with vortex. Then centrifuged at $500 \mathrm{rpm}$ for 10 minutes. Supernatant was taken, transferred to new tubes. The solution was further incubated in the waterbath with temperature $100^{\circ} \mathrm{C}$ for 30 minutes, at room temperature. Futhermore, the supernatant absorbance was measured with a spectrophotometer at maximum wave length $(530 \mathrm{~nm})$, and plotted on standard curve that has been made to calculate the concentration of MDA.

\section{RESULT AND DISCUSSION}

\section{Result Protein Analysis of Goat Milk Fermented}

Fig. 1. prove that the fermentation process causes the breakdown of peptides in goat milk. It can be seen from the number of protein bands were formed from SDS PAGE electrophoresis process more than the amount of protein bands on goat's milk.

Table I. The composition of the feed material hypercholesterolemia in $\mathbf{2 0}$ grams of feed Ingredients Ingredients Amount (\%) Amount Ingredients (g)

\begin{tabular}{lcc}
\hline \multicolumn{1}{c}{ Ingredients } & Composition (\%) & Total (gram) \\
\hline Cholic Acid & 0.1 & 0.02 \\
Lard Oil & 10 & 2 \\
Quail fresh yellow egg & 5 & 1 \\
\hline
\end{tabular}




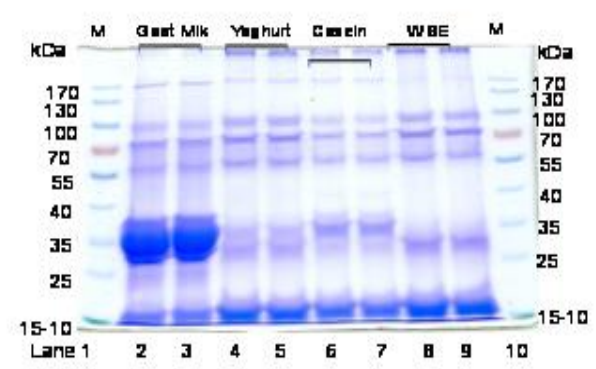

Figure I. Profile protein on goat milk protein

Decomposition of peptides in milk known to be optimal because of the hydrolysis process and the presence of lactic acid bacteria in the fermentation process. With a large variety of peptides contained in goat's milk yogurt, characterization stages necessary to obtain peptides that are known to work to lower cholesterol levels in the blood. Characterization is done by performing fractionation hydrolyzed protein which has a $\mathrm{BM}<3 \mathrm{kDa}$ which is known to be anti-hypercholesterolemia. Such separation is shown in Fig. 2.

Results from this process is then performed characterization of peptides using LC-MS/MS are shown in Fig. 3.
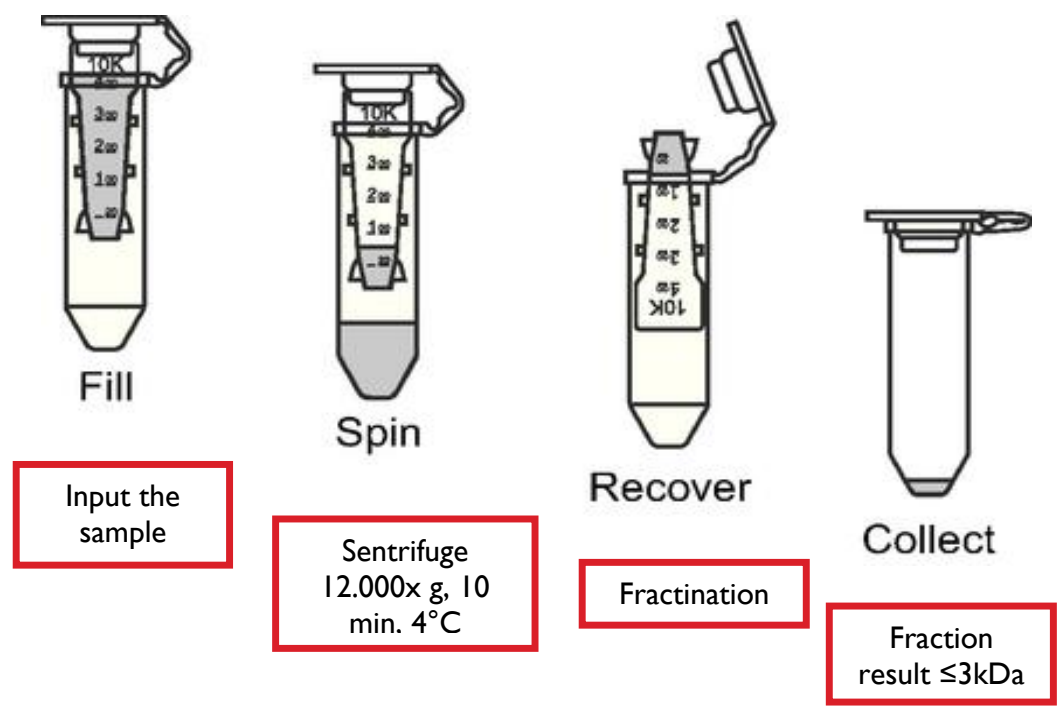

Figure 2. Fractionation processing of protein hydrolysat $<3 \mathrm{kDa}$

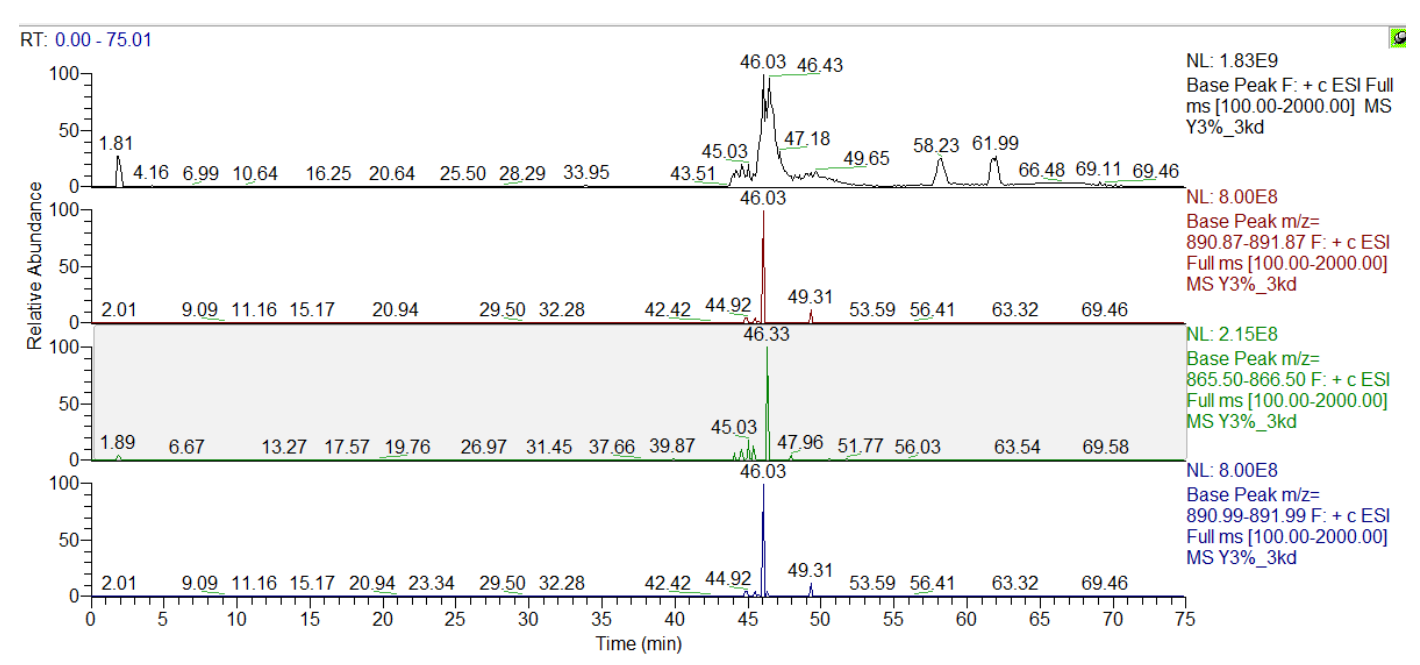

Figure 3. LC-MS / MS chromatograms of samples yoghurt $<3 \mathrm{kDa}$ 
Fig. 3. prove that the fermentation process causes the breakdown of peptides in goat milk. It can be seen from the number of protein bands were formed from SDS PAGE electrophoresis process more than the amount of protein bands on goat's milk. Decomposition of peptides in milk known to be optimal because of the hydrolysis process and the presence of lactic acid bacteria in the fermentation process. With a large variety of peptides contained in goat's milk yogurt, characterization stages necessary to obtain peptides that are known to work to lower cholesterol levels in the blood. Characterization is done by performing fractionation hydrolyzed protein which has a $\mathrm{BM}<3 \mathrm{kDa}$ which is known to be antihypercholesterolemia. Such separation is shown in Table 2.

Results of the isolation and characterization of bioactive peptides obtained three kinds of bioactive peptides, each of which consists of 16 amino acids which is securely protected from the digestive tract protease enzyme. These peptides were tested for anti-hypercholesterol activity through the preparation of animal models treated hypercholesterolemic diet.

\section{The Liver Histopathology}

The process of making preparations histopathology consisted of fixation, dehydration and infiltration, purification, paraffin infiltration, embedding, sectioning, pasting on a glass object, and staining. Fixation is done to prevent damage to the tissue, stop the process of metabolism and harden soft material so that the network can be colored. Fixation is done by the network put in 4\% PFA solution.

Hematoxylin eosin staining (HE) is done to look at the morphology of liver tissue. Staining begins with deparafination and rehydration preparations using xylol and alcohol-rise 95\%, 90\%, $80 \%$ and $70 \%$. Preparat then washed with running water and distilled water. The process of staining was performed using Hematoxylin for 1 minute and eosin dye for 5 minutes. After the preparations colored, made of dehydrated with alcohol $70 \%, 80 \%$, $90 \%$ and $95 \%$ and continued with absolute alcohol I, II and III respectively 5 minutes. Once that is done Clearing process with xilol I and II for 5 minutes, preparations wind dried and covered with cover glass.

Histopathological observations of liver tissue preparations using a light microscope Olympus BX51 started weak magnification (40x) to powerful magnification (1000x) by 5 field of vision to see the changes in the structure and shape of the heart tissue. Histopathological picture liver tissue magnification 100x, 400x and 1000x analyzed descriptively. Calculation of changes in the liver tissue of the controls is converted into a percentage using the formula of the average percentage of area treatment groups was reduced by an average percentage of area groups with an average control shared control multiplied by $100 \%$.

Tabel II. Results of identification of peptide samples yogurt $<3 \mathrm{kDa}$ using distiller mascot and NCBI database

\begin{tabular}{lcccc}
\hline $\begin{array}{c}\text { Peptide sequences } \\
\text { identified }\end{array}$ & $\mathbf{M / Z}$ & $\begin{array}{c}\text { Molecular } \\
\text { Weight } \\
\text { (Da) }\end{array}$ & $\begin{array}{c}\text { Score } \\
\text { time }\end{array}$ \\
\hline LYQEPVLGPVRGPFPI & 891.37 & 1780.90 & 50 (homolog) & 46.03 \\
YQEPVLGPVRGPFPIL & 891.49 & 1780.90 & 52 (homolog) & 46.03 \\
VQSWMHQPPQPLSPT & 866.88 & 1731.84 & 51 (homolog) & $45.03 ; 46.33$ \\
\hline
\end{tabular}

Table III. On average liver MDAlevels in the treatment group

\begin{tabular}{ccc}
\hline Groups & Average level MDA $(\mu \mathrm{g} / \mathrm{ml})$ & $\begin{array}{c}\text { The content } \\
\text { of MDA(\%) }\end{array}$ \\
\hline A & $2.44 \pm 0.24^{\mathrm{a}}$ & 40.20 \\
B & $6.07 \pm 0.56^{\mathrm{c}}$ & 100.00 \\
C & $4.79 \pm 0.36^{\mathrm{b}}$ & 78.91 \\
D & $3.33 \pm 0.59 \mathrm{a}$ & 54,86 \\
E & $2.50 \pm 0.5 \mathrm{la}$ & 41.67 \\
\hline
\end{tabular}

Description: The difference notation $\mathrm{a}, \mathrm{b}$ and $\mathrm{c}$ show a highly significant difference $(p<0.0 \mathrm{I})$ between the treatment groups. 
Effect of Goat Milk Yoghurt Therapy Against Malondialdehida levels (MDA) Organ Animal Liver Model Rat (Rattus norvegicus) Hypercholesterolemia

The average results of liver MDA levels in the treatment group (Table 3) Showed a highly significant difference between treatments $(p<0.01)$ ANOVA results MDA in rats treated showed a highly significant difference $(p<0.01)$. At Table 2 known that group of control mice (A) has an average of the lowest levels of liver MDA is $2.44 \pm 0.24$ $\mathrm{pg} / \mathrm{mL}$, while groups of mice hypercholesterolemia (B) has an average of the highest levels of liver MDA is $6.07 \pm 0.56 \mathrm{ug} / \mathrm{mL}$. Goat's milk yoghurt therapy at a dose of $300 \mathrm{mg} / \mathrm{kg}, 600 \mathrm{mg} / \mathrm{kg}$, and 900 $\mathrm{mg} \mathrm{kg}$ body weight can reduce levels of hypercholesterolemic mice MDA respectively $78.91 \%$; $54.86 \%$; and $41.67 \%$. A group of rats had the lowest levels of MDA because only given normal feed so that the levels of cholesterol in the blood is still in the normal range is $10-54 \mathrm{mg} / \mathrm{dL}$, with content of MDA $2.44 \pm 0.24$ or $40.20 \%$. Cholesterol would trigger the formation of free radicals, but the number of free radicals in mice A group does not exceed the amount of antioxidants found in the body so that the antioxidant is able to capture free radicals and inhibiting lipid peroxidation. In mice group B has the highest MDA levels because rats fed a diet containing kolesterol 240.50 hypercholesterolemia $\mathrm{mg}$ cholesterol levels significantly different to the condition of the body will try to normal balance so cholesterol to bile acid synthesis. Side effects of bile acid synthesis in the form of free radicals that trigger lipid peroxidation. Lipid peroxidation will form MDA as product of reactive metabolites, biomarkers for assessing oxidative stress. Total cholesterol is more and more in the body will increase the synthesis of bile acids so that more and more free radicals are produced. Increased free radicals will result in more MDA generated from lipid peroxidation process. These results are consistent with studies conducted Fki, et al., (2005) that the group of mice that were fed a rich cholesterol diet will increase malondialdehida (MDA) in hearts compared with the normal group. Giving goat milk yogurt can provide a very real effect on mice hypercholesterolemia. Goat's milk yogurt contains antioxidant compounds that can capture free radicals produced as a side effect of bile acid synthesis. Antioxidant function as a catcher of free radicals and inhibiting lipid peroxidation process so that it can help reduce levels of free radicals as a result of the provision of hiperkolesterol. Peroxidation inhibitor process dietary lipids by capturing free radicals and donate a hydrogen atom to form stable compounds that able to stop the chain reaction of lipid peroxidation. Milk has biopeptida active content that can be generated through hydrolysis by the digestive enzymes and enzymatic processes by microorganisms. Lactic acid bacteria in yogurt can ferment milk to produce active biopeptida, such as lactoferrin.

Lactoferrin is able to repair cell damage by inhibiting the production of ROS in the cell membrane and works with vitamin $\mathrm{E}$ in limiting membrane lipid oxidation by ROS. Lactoferrin according to Guillen (2013) is an iron binding extracelullar. Intracellular iron called heme and stored in the form of ferritin, extracellular bound by transferrin or lactoferrin protein. Iron that is not bound will catalyze the production of ROS, then through biopeptide extracellular iron lactoferrin will be bound so that inhibited ROS generation.

Yogurt also contains lactic acid bacteria have enzymes Bile Salt Hydrolase (BSH) so as to deconyugate bile salts to produce bile salts that poorly absorbed by the small intestine. Bile salts return to the liver to be reduced so that the body uses cholesterol as a precursor to balance the amount of bile salts that decrease the amount of cholesterol. Decrease in cholesterol levels resulted in a decrease in the amount of lipids which are exposed to free radicals is reduced so that the process is reduced lipid peroxidation accompanied by a decrease in the sheer number of levels of MDA in the liver of animal models of rats (Rattus norvegicus) hypercholesterolemia. 

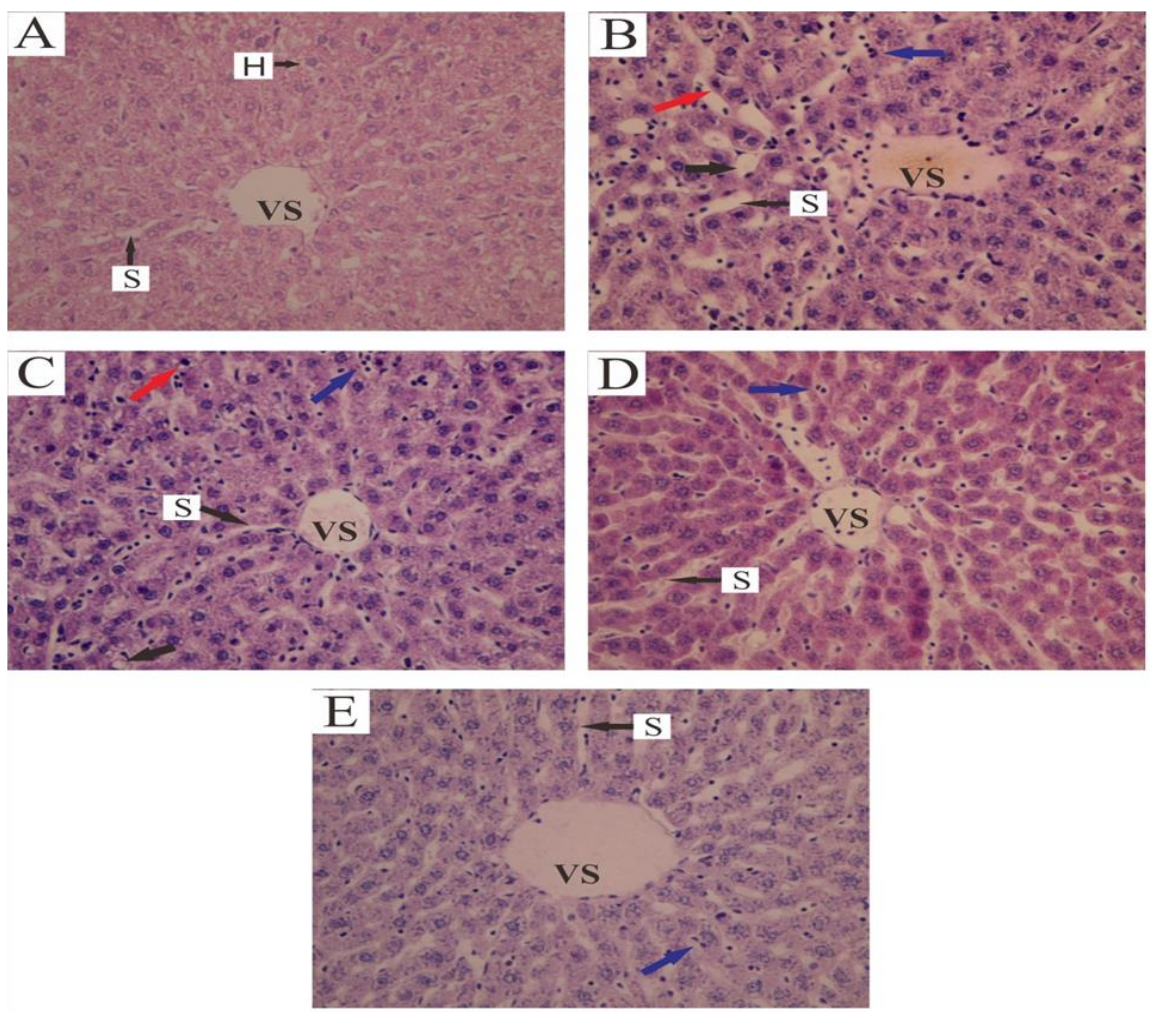

Figure 4. Histopathological picture liver mice models (Rattus norvegicus) hypercholesterolemia treated goat milk yogurt with a magnification of $\mathbf{4 0 0}$. (A) The negative control group of rat; (B) The positive group of rat (hypercholesterolmia); (C) The group of rat hypercholesterolmia with yogurt therapeutic dose of $300 \mathrm{mg} / \mathrm{kg}$ BW; (D) The group of rat hypercholesterolmia with yogurt therapeutic dose of $600 \mathrm{mg} / \mathrm{kg} \mathrm{BW;} €$ The group of rat hypercholesterolmia with yogurt therapeutic dose of $900 \mathrm{mg} / \mathrm{kg} \mathrm{BW}$.

Fig. 4. showed that the administration of fermented goat milk or yogurt can improve the structure of rat hepar damaged by feeding hypercholesterolemia treatment. The structure of the liver is the most damage was hepatic control rats positif group, with the content of $6.07 \pm 0.56(100 \%)$, with liver cell structure that much damage, which is marked by a lot of empty space and fatting.

The structure of rat liver cells the most good is reats with negative control group (A) with the content of MDA $2.44 \pm 0,24 \mu \mathrm{g} / \mathrm{mL}$ or $(40.20 \%)$ with the liver cell structure relatively undamaged which is characterized but relatively no empty space and unfattening. Group of rats C, D and E there were improvement of liver structures, because of their treatment of fermented goats milk of each $300 \mathrm{mg} / \mathrm{kg}$ BW; $600 \mathrm{mg} / \mathrm{kg} \mathrm{BW}$ and $900 \mathrm{mg} / \mathrm{kg} \mathrm{BW}$. Its characterized by decreasing content of MDA in group $\mathrm{C}, \mathrm{D}$ and $\mathrm{E}$ respectively are as follow: $4.79 \pm 0.30 \mu \mathrm{g} / \mathrm{mL} \quad(78.41 \%) ; \quad 3.33 \pm 0.59 \mu \mathrm{g} / \mathrm{mL}$ $(54.86 \%)$ and $2.50 \pm 0.56 \mu \mathrm{g} / \mathrm{mL}$ (41.67\%). The supplementation of fermented goats milk which acts as source of antioxidants, source of bioactive peptide and source of lactic acid bacillus that can capture and degradation free radical and lower the body cholesterol that affected by feeding hypercholesterolemia. This is in according with opinion of Fki, et al., 2005; Korhonen and Pilanto, 2006; and Donker et al., 2007. That fermented milk as source of bioactive peptides, source of antioxidant that able to provide the best therapeutic effect in lowering levels of MDA and therapeutiv effect in reducing the expression fat accumulation liver rat animal model of hypercholesterolemia.

\section{CONCLUSION}

Goat milk yogurt can reduce levels of MDA and decreased fats accumulation of animal model of hypercholesterolemia. Goat's milk yoghurt therapy at a dose of $900 \mathrm{mg} / \mathrm{kg}$ BW has been able to provide the best therapeutic effect in lowering levels of MDA and therapeutic dose of $900 \mathrm{mg} / \mathrm{kg}$ give the best therapeutic effect in reducing the expression fat accumulation liver rat animal model of hypercholesterolemia. 


\section{ACKNOWLEDGMENT}

We grateful to acknowledge Prof Dr. Aulaniam DESS The Vice Dean of Veterinery Program: Staff Laboratory of Veterinary Public Health, Veterinary Medicine Program, University of Brawijaya, Malang. Staff Laboratory of Pharmacognosy and Phytochemistry Faculty of Pharmacy, University of Airlangga, Surabaya. Staff Laboratory of Biochemistry, University of Brawijaya, Malang. Staff Laboratory of Animal Physiology, Faculty of Mathematics and Natural Sciences, University of Brawijaya, Malang for support for this research and study.

\section{REFERENCES}

Ebringer, L., Ferenčík M. and Krajčovič. J., 2008, Beneficial Health Effects of Milk and Fermented Dairy Products, Folia Microbiol., 53(5), 378-394.

Fki, I., Bouaziz, M., Sahnoun, Z. and Sayadi, S., 2005, Hypocholesterolemic Effects on Phenolic-rich Extract of Chemlali Olive Cultivar in Rats Fed a cholesterol-rich diet, Bioorg. Med. Chem., I3(I8), 5362-5370.

Kitts, D.D. and Weiler, K., 2003, Bioactive Proteins and Peptides from Food Sources. Applications of Bioprocesses Used in
Isolation and Recovery, Cur. Pharm. Design, 9(16), 1309-1323.

Korhonen, H., 2009, Milk-derived Bioactive Peptides: From Science to Applications, J. Func. Foods, I(2), I77-187.

Korhonen, H. and Pihlanto, A., 2003, Food-derived Bioactive Peptides-Opportunities for Designing Future Foods, Cur. Pharm. Design, 9, 1297-1308.

Lamothe, S., Robitaille, G., St-Gelais, D. and Britten, M., 2007, Short Communication: Extraction of B-casein from Goat Milk, J. Dairy Sci., 90(I2), 5380-5382.

McCullough, F.S.W., 2003, Nutritional Evaluation of Goat's Milk, British Food Journal, 105(4/5), 239-25I.

Donkor, O.N. and Henriksson, A., Singh, T.K., Vasiljevic, T. and Shah, N.P., 2007, ACEinhibitory Activity of Probiotic Yoghurt, Int. Dairy J., I7(II), |32|-|33|.

Paul, M. and Somkuti, G.A., 2010, Degradation of milk- based bioactive peptides by yogurt fermentation bacteria, Lett. Appl. Microbiol., 49(3), 345- 350.

Samardi, B.H. and Ismail, 2010, Antioxidative Peptides from Food Protein: A Review, Peptida, 3 I (I0), 1949- 1956.

Walther, B. and Sieber, R., 20II, Bioactive Proteins and Peptides in Foods, Int. J. Vitam. Nutr. Res., 8 I (2-3), I8I- 192. 